\title{
Ellagitannins of Davidia involucrata. I. Structure of Davicratinic Acid A and Effects of Davidia Tannins on Drug-Resistant Bacteria and Human Oral Squamous Cell Carcinomas
}

\author{
Yuuki Shimozu ${ }^{1}$, Yuriko Kimura ${ }^{1}$, Akari Esumi ${ }^{1}$, Hiroe Aoyama ${ }^{1}$, Teruo Kuroda ${ }^{2}$, \\ Hiroshi Sakagami ${ }^{3}$ and Tsutomu Hatano ${ }^{1, *}$ \\ 1 Graduate School of Medicine, Dentistry and Pharmaceutical Sciences, Okayama University, \\ Okayama 700-8530, Japan; yshimozu@okayama-u.ac.jp (Y.S.); ph422109@s.okayama-u.ac.jp (Y.K.); \\ pelp67gx@s.okayama-u.ac.jp (A.E.); ph20101@s.okayama-u.ac.jp (H.A.) \\ 2 Department of Molecular Microbiology and Biotechnology, Graduate School of Biomedical and Health \\ Sciences, Hiroshima University, Hiroshima 734-8553, Japan; tkuroda@hiroshima-u.ac.jp \\ 3 Division of Pharmacology, Department of Diagnostic and Therapeutic Sciences, School of Dentistry, \\ Meikai University, Saitama 350-0283, Japan; sakagami@dent.meikai.ac.jp \\ * Correspondence: hatano@pharm.okayama-u.ac.jp; Tel.: +81-86-251-7936; Fax: +81-86-251-7926
}

Academic Editor: Derek J. McPhee

Received: 11 February 2017; Accepted: 12 March 2017; Published: 15 March 2017

\begin{abstract}
We isolated a new ellagitannin, davicratinic acid A (5), together with four known ellagitannins, davidiin (1), granatin A (2), pedunculagin (3), and 3-O-galloylgranatin A (4), from an aqueous acetone extract of dried Davidia involucrata leaves. The known ellagitannins were identified based on spectroscopic data. The structure of davicratinic acid A (5), a monomeric ellagitannin possessing a unique, skew-boat glucopyranose core, was established based on spectroscopic data. Additionally, we examined the effects of several tannins with good yields from this plant on drug-resistant bacteria and human oral squamous cell carcinomas, and found that davidiin (1) exhibited the most potent antibacterial and antitumor properties among the tannins examined.
\end{abstract}

Keywords: Davidia involucrata; ellagitannin; anti-bacterial effect; antitumor effect; davicratinic acid A

\section{Introduction}

Davidia involucrata Baill., known as the dove tree or handkerchief tree, is the sole species of the genus Davidia of the family Davidiaceae (as per the Engler system) [1]. Although it has been cultivated as an ornamental tree, its natural habitat is limited to a region in southern China. A number of constituents including phenolics [2] and triterpenes [3,4] have been identified from its branch bark. More significantly, this plant has been shown to contain ellagitannins [5]. Ellagitannins, a large group of polyphenolic compounds widely distributed in plants, are often encountered as the constituents of food, beverages, and medicinal plants [6]. Ellagitannins from various plant sources have been demonstrated to have notable antiviral, antimicrobial, and antitumor properties [7]. The isolation of davidiin (1) and granatin A (2) (Figure 1) as major tannins from D. involucrata leaves was reported in 1982 [5]. Among them, $\mathbf{1}$ is a unique ellagitannin possessing a skew-boat glucopyranose core. Recently, this compound has been identified as an inhibitor of the protein modification called SUMOylation in a post-translational process in which the inhibitor suppresses the formation of the small ubiquitin-like modifier (SUMO)-activating enzyme-SUMO-1 intermediate [8]. Despite this discovery, there are few reports of additional chemical research on its constituents, probably due to the scarcity of this plant species. 
Infectious diseases caused by multidrug-resistant bacteria, including methicillin-resistant Staphylococcus aureus (MRSA) and vancomycin-resistant Enterococci (VRE), have become serious problems worldwide [9]. To date, research has been focused on developing antibacterial agents against MRSA and VRE. The synergistic effects of ellagitannins with antibiotics against drug-resistant bacteria are among the most notable antimicrobial activities of tannins [10]. Our recent studies have revealed that several phenolic compounds exhibited potent anti-VRE activity [11,12]. Accordingly, it is expected that ellagitannins from D. involucrata also have potent antibacterial effects against MRSA and VRE.

Several lines of evidence suggest that tannins have important antitumor properties, such as inhibition of tumor promotion $[13,14]$ and inhibition of carcinogen mutagenicity [15]. Recent evidence includes the inhibitory effects of $\mathbf{1}$ on cell proliferation and tumor growth in hepatocellular carcinomas by downregulating EZH2 via a proteasome-dependent mechanism [16]. The cytotoxic effects of ellagitannin monomers and dimers from Tamarix nilotica against human oral squamous cell carcinomas (OSCC) [17-19], depending on their structures, have been shown in our previous studies.

In this study, we isolated a new ellagitannin, together with four known ones, from the leaves of D. involucrata, and determined the antibacterial effects of Davidia tannins on antibiotic-resistant bacteria (MRSA and VRE) and the cytotoxic effects on OSCC (Ca9-22, HSC-2, HSC-3, and HSC-4) cell lines.

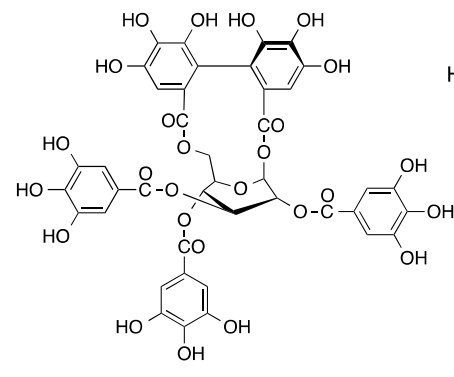

Davidiin (1)

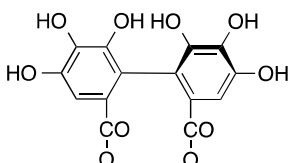

$0)$

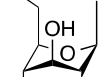

$0 \quad 0$

co co

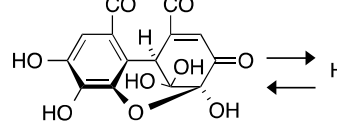

Granatin A (2)

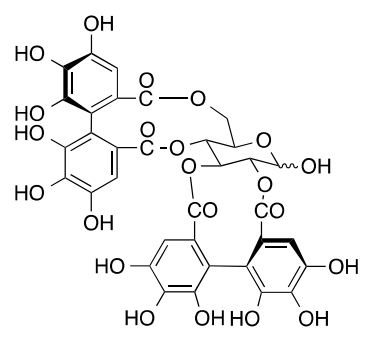

Pedunculagin (3)

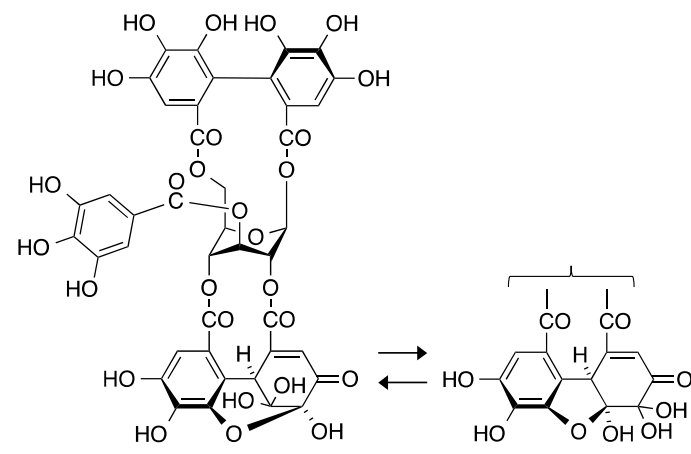

3-O-Galloylgranatin A (4)

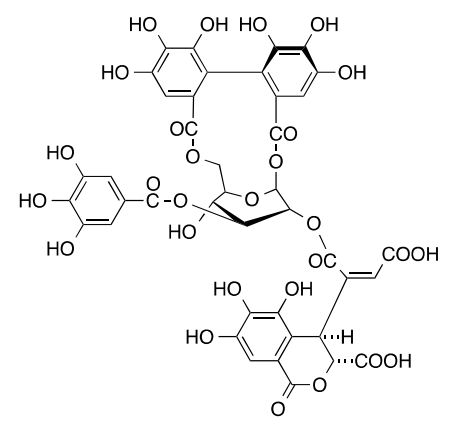

Davicratinic acid A (5)

Figure 1. Structures of hydrolysable tannins isolated from Davidia involucrata.

\section{Results and Discussion}

\subsection{Elucidation of the Structure of the New Ellagitannin}

An aqueous acetone homogenate of the dried leaves of D. involucrata was extracted successively with chloroform, ethyl acetate, and $n$ - $\mathrm{BuOH}$. In addition to the four known tannins obtained from the $n$ - $\mathrm{BuOH}$ extract, davicratinic acid A (5) was isolated as a new ellagitannin from the $\mathrm{H}_{2} \mathrm{O}$ extract. 
The known tannins were identified as davidiin (1) [7,20], granatin A (2) [7], pedunculagin (3) [21], and 3-O-galloylgranatin A (helioscopinin A) (4) [22] (Figure 1) based on the ${ }^{1} \mathrm{H}-\mathrm{NMR}$ and ESI-MS data.

Davicratinic acid A (5) was obtained as a pale yellow amorphous powder. High-resolution electrospray ionization mass spectrometry (HR-ESI-MS) in the positive ion mode showed the $[\mathrm{M}+\mathrm{H}]^{+}$ ion peak corresponding to the molecular formula $\mathrm{C}_{41} \mathrm{H}_{31} \mathrm{O}_{28}$. The ${ }^{1} \mathrm{H}-\mathrm{NMR}$ spectrum of 5 showed that the signals were due to a galloyl group $(\delta 7.03,2 \mathrm{H}, \mathrm{s})$ and a $4,4^{\prime}, 5,5^{\prime}, 6,6^{\prime}$-hexahydroxydiphenoyl (HHDP) group $(\delta 6.74$ and 6.89 , each $1 \mathrm{H}, \mathrm{s})$. In addition, the spectrum exhibited sugar signals at $\delta 3.93(1 \mathrm{H}, \mathrm{dd}$, $J=4.8,7.8 \mathrm{~Hz}), 4.04(1 \mathrm{H}, \mathrm{dd}, J=4.8,11.4 \mathrm{~Hz}), 4.26(1 \mathrm{H}, \mathrm{dt}, J=4.8,11.4 \mathrm{~Hz}), 4.60(1 \mathrm{H}, \mathrm{t}, J=11.4 \mathrm{~Hz})$, $5.13(1 \mathrm{H}, \mathrm{dd}, J=3.6,7.8 \mathrm{~Hz}), 5.37(1 \mathrm{H}, \mathrm{t}, J=7.8 \mathrm{~Hz})$, and $5.88(1 \mathrm{H}, \mathrm{d}, J=3.6 \mathrm{~Hz})$, which were assigned to the glucose $\mathrm{H}-4, \mathrm{H}-6 \mathrm{a}, \mathrm{H}-5, \mathrm{H}-6 \mathrm{~b}, \mathrm{H}-2, \mathrm{H}-3$, and $\mathrm{H}-1$ signals based on ${ }^{1} \mathrm{H}-{ }^{1} \mathrm{H}-\mathrm{COSY}$. The appearance of the $\mathrm{H}-4$ signal in the higher field indicated that the $\mathrm{C}-4$ hydroxyl group was unacylated. According to the coupling constants of these glucose proton signals, the glucopyranose ring in $\mathbf{5}$ was assigned a skew-boat-type conformation. The HMBC spectrum revealed that glucose $O-3$ was acylated by the galloyl group and the $O-1$ and $O-6$ positions of glucose were bridged via the HHDP group (Figure 2a). The HMBC spectrum of 5 also showed couplings of the singlet protons at $\delta 6.83\left(\mathrm{H}-5^{\prime}\right)$ and $5.49\left(\mathrm{H}-3^{\prime}\right)$ with a carboxyl carbon signal at $\delta 165.5\left(\mathrm{C}-7^{\prime}\right)$ of the remaining acyl group. Because this carboxyl carbon signal was further correlated with the glucose $\mathrm{H}-2$ signal, the acyl group containing these protons and carbons is connected to glucose $\mathrm{O}-2$. The HMBC spectrum also showed correlations with the methine proton signals at $\delta 5.15\left(\mathrm{H}-2^{\prime}\right)$ and $5.49\left(\mathrm{H}-3^{\prime}\right)$ with a carboxyl carbon signal at $\delta 171.4\left(\mathrm{C}-1^{\prime}\right)$, and those of two methine proton signals $\left(\delta 5.15\left(\mathrm{H}-2^{\prime}\right), 7.10\left(\mathrm{H}-3^{\prime \prime}\right)\right)$ with a carboxyl carbon signal $(\delta 166.8$ $\left.\left(\mathrm{C}-\mathrm{7}^{\prime \prime}\right)\right)$. These spectral observations led us to formulate a dehydrochebuloyl group for the acyl group at glucose $\mathrm{O}-2$. $\mathrm{H}-5^{\prime}$ showed an ROE correlation between $\mathrm{H}-2^{\prime}$ and $\mathrm{H}-3^{\prime}$, indicating that the geometrical isomerism of the double bond was $Z$ (Figure $2 b$ ). To determine the stereochemistry of 5 , the ECD spectra of 5 and repandusinic acid A (6) (Figure 3a) [23], which also possesses the galloyl, HHDP, and dehydrochebuloyl groups, were compared. As shown in Figure 3b, the spectrum of 5 displayed the ECD pattern with the opposite signs of that of 6 . Therefore, the stereochemistry of the HHDP group in 5 is $S$, whereas both $C-2^{\prime}$ and $C-3^{\prime}$ of the dehydrochebuloyl group are $R$. Based on the above data, 5 was identified as 1,6-O-(S)-HHDP-2-O-( $\left.2^{\prime} R, 3^{\prime} R\right)-\left(4^{\prime}\right.$-dehydrochebuloyl)-3-O-galloyl- $\beta$-D-glucose (The data are also given in Figures S1-S7 in the supplementary material).

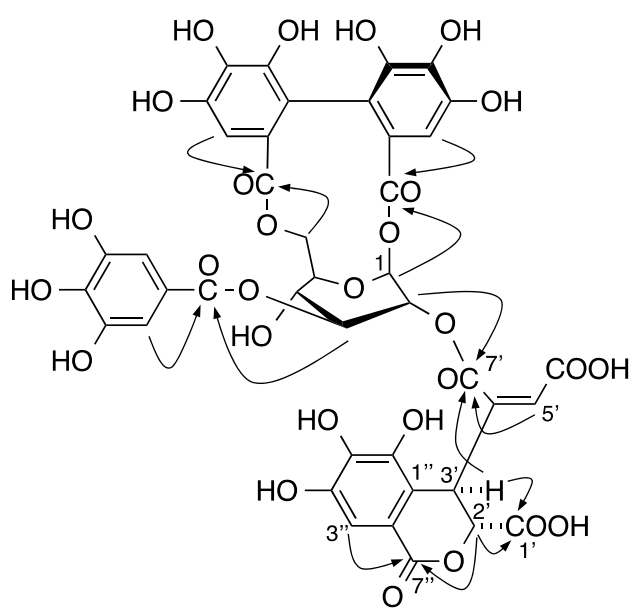

(a)

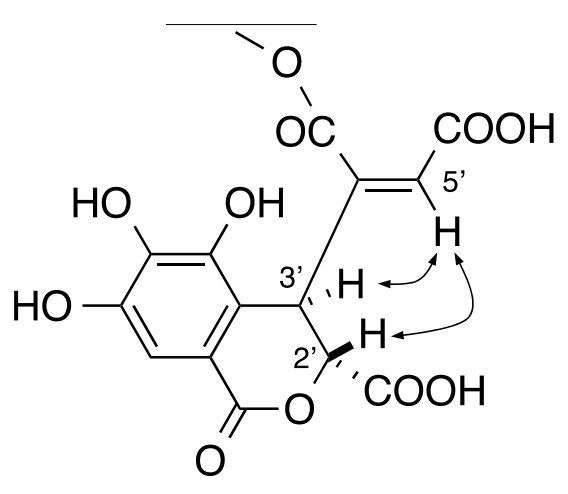

(b)

Figure 2. Key HMBC (a) and ROESY (b) correlations of davicratinic acid A (5). 


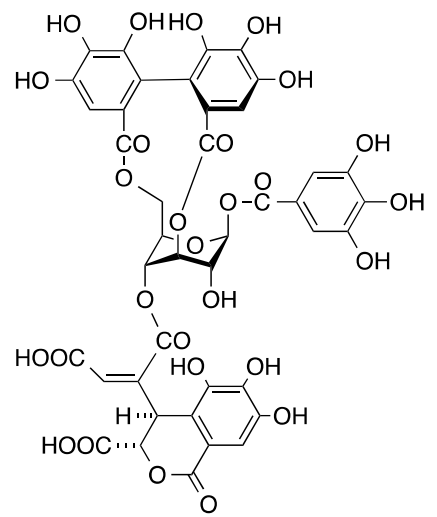

Repandusinic acid A (6)

(a)

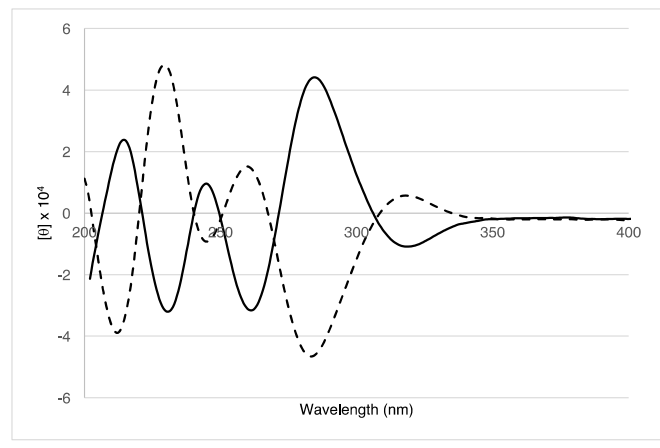

(b)

Figure 3. Determination of the stereochemistry of davicratinic acid A (5). (a) Structure of repandusinic acid A (6); (b) Comparison of the ECD spectra between 5 (solid line) and $\mathbf{6}$ (dashed line).

\subsection{Biological Effects of Davidia Tannins}

\subsubsection{Antibacterial Effects}

To clarify the biological properties of Davidia tannins, we examined the major tannin $\mathbf{1}$ and related tannins 2 and 4, obtained in high yield from D. involucrata, for antibacterial effects on MRSA (S. aureus OM481 and OM584) and VRE (E. faecium FN-1 and E. faecalis NCTC12201) by the liquid dilution method [24]. The results are summarized in Table 1, and $\mathbf{1}$ and $\mathbf{4}$ exhibited antibacterial effects on both MRSA $(64 \mu \mathrm{g} / \mathrm{mL})$ and VRE (16-64 $\mu \mathrm{g} / \mathrm{mL})$. In particular, compound 1 showed the most potent effect on E. faecalis NCTC12201. The galloyl group is related to antibacterial properties; 1, which possesses three galloyl groups, exhibited the most potent activity (MIC $64 \mu \mathrm{g} / \mathrm{mL}$ for MRSA, $16 \mu \mathrm{g} / \mathrm{mL}$ for VRE). Conversely, compound 2, which is composed of HHDP and dehydrohexahydroxydiphenoyl (DHHDP) groups but no galloyl groups, was ineffective. It has been reported that the extract containing ellagitannins of Acalypha wilkesiana var. macafeana exerts antibacterial effects by causing cell wall damage which eventually results in cell lysis [25]. Besides, the significance of the galloyl group in polyphenols on the instability of cell membrane was also reported [26]. Hence, there is a possibility that 1 and 4 exhibited antibacterial activities by the disruption of the cell membrane. Further studies using other bacterial strains/species and those clarifying the mechanisms for the antibacterial effects are needed.

Table 1. Antibacterial effects of Davidia tannins. ${ }^{\text {a }}$

\begin{tabular}{|c|c|c|c|c|}
\hline \multirow{4}{*}{ Compounds } & \multicolumn{4}{|c|}{ MIC $(\mu \mathrm{g} / \mathrm{mL})$} \\
\hline & \multirow{2}{*}{\multicolumn{2}{|c|}{$\begin{array}{c}\text { MRSA } \\
\text { S. aureus }\end{array}$}} & \multicolumn{2}{|c|}{ VRE } \\
\hline & & & \multirow{2}{*}{$\begin{array}{c}\text { E. faecium } \\
\text { FN-1 }\end{array}$} & \multirow{2}{*}{$\begin{array}{c}\text { E. faecalis } \\
\text { NCTC12201 }\end{array}$} \\
\hline & OM481 & OM584 & & \\
\hline 1 & 64 & 64 & $>128$ & 16 \\
\hline 2 & 128 & 128 & $>128$ & 128 \\
\hline 4 & 64 & 64 & $>128$ & 64 \\
\hline Linezolid & 2 & 1 & 2 & 2 \\
\hline
\end{tabular}

a The acronyms used are: MIC, minimum inhibitory concentration; MRSA, methicillin-resistant Staphylococcus aureus; VRE, vancomycin-resistant Enterococci

\subsubsection{Cytotoxic Effects}

Among various types of tannins, dimeric ellagitannins specifically displayed host-mediated antitumor activity against sarcoma-180 in mice [27]. Recently, in vitro studies using tumor cell lines 
have shown that monomeric, dimeric, and oligomeric ellagitannins show potent cytotoxicity against carcinoma cell lines and lower cytotoxicity to normal cells [17-19,28]. It has also been reported that 1, a monomeric ellagitannin, inhibits cell proliferation and tumor growth in hepatocellular lines [16]. Thus, we also examined 1 and 4, which showed antibacterial activities, for their cytotoxic activities on human OSCC (Ca9-22, HSC-2, HSC-3, and HSC-4) compared with their activities on human oral normal cells (HGF, HPC, and HPLF).

As shown in Table 2, both 1 and 4 exhibited moderate cytotoxicity toward OSCC. In addition, 1 showed a higher tumor-specificity (TS) index than 4. Although the effect of $\mathbf{1}(\mathrm{TS}=2.2)$ was lower than several oligomeric tannins (TS = 2.1-7.1) [17-19], its activity was higher than that of other types of natural polyphenols (flavones, flavonols, and isoprenylated flavonoids) (TS = 1.2-2.3) and terpenes (triterpene aglycones and triterpene glycosides) (TS = 1.2-1.6) [29]. It should be noted that it is comparable with that of resveratrol, which is a natural potent antitumor compound (TS $=2.9$ ). It seems that a larger number of phenolic hydroxyl groups on galloyl and related acyl groups in hydrolyzable tannins increase the tumor specificity. However, our previous study suggested that pentagalloylglucose is non-cytotoxic practically [28]. Therefore, these results suggest that the tumor specificity of tannins depends largely on the structure, and especially the skew-boat glucopyranose core affecting the orientations of the acyl groups may play an important role in the cytotoxicity.

Table 2. Cytotoxicity of Davidia tannins against human normal and tumor cells. ${ }^{a}$

\begin{tabular}{ccccccccc}
\hline & \multicolumn{9}{c}{ CC $_{50} \pm$ SD $(\mu \mathrm{M}){ }^{\mathbf{b}, \mathbf{c}}$} \\
\cline { 2 - 9 } Compounds & \multicolumn{7}{c}{ Human Tumor Cells } & \multicolumn{4}{c}{ Human Normal Oral Cells } \\
\cline { 2 - 9 } & Ca9-22 & HSC-2 & HSC-3 & HSC-4 & HGF & HPLF & HPC & TS ${ }^{\text {d }}$ \\
\hline $\mathbf{1}$ & $140 \pm 8.7$ & $112.3 \pm 11.2$ & $99.6 \pm 8.6$ & $152.7 \pm 13.6$ & $254.7 \pm 16.3$ & $309.0 \pm 12.8$ & $256 \pm 28.8$ & 2.2 \\
$\mathbf{4}$ & $97.3 \pm 9.0$ & $111.0 \pm 3.5$ & $114.7 \pm 14.5$ & $95.3 \pm 22.3$ & $128.7 \pm 3.8$ & $155.0 \pm 11.4$ & $131.0 \pm 1.7$ & 1.3 \\
Resveratrol & $106 \pm 6.0$ & $71.0 \pm 0.6$ & $67.7 \pm 1.3$ & $46.2 \pm 6.9$ & $215.0 \pm 29.7$ & $198.3 \pm 22.3$ & $214.0 \pm 12.1$ & 2.9 \\
\hline
\end{tabular}

${ }^{a}$ See also Table $\mathrm{S} 1$ in the supplementary material; ${ }^{\mathrm{b}} \mathrm{CC}_{50}, 50 \%$ cytotoxic concentration; ${ }^{\mathrm{c}}$ Each value represents the mean from three independent experiments; ${ }^{\mathrm{d}} \mathrm{TS}$, tumor-specificity index.

\section{Materials and Methods}

\subsection{General Experimental Procedures}

One-dimensional (1D) $\left({ }^{1} \mathrm{H}\right.$ and $\left.{ }^{13} \mathrm{C}\right)$ and two-dimensional (2D) $\left({ }^{1} \mathrm{H}-{ }^{1} \mathrm{H}\right.$ COSY, ROESY, HSQC, and HMBC) NMR spectra were recorded on a Varian NMR system $600\left(600 \mathrm{MHz}\right.$ for ${ }^{1} \mathrm{H}$ and $151 \mathrm{MHz}$ for ${ }^{13} \mathrm{C}$, Agilent Technologies, Santa Clara, CA, USA). Chemical shifts are reported in $\delta(\mathrm{ppm})$ values relative to that of the solvent signal (acetone- $d_{6}\left(\delta_{\mathrm{H}} 2.04 ; \delta_{C} 29.8\right)$ ) on the tetramethylsilane scale. Optical rotations were recorded on a JASCO DIP-1000 digital polarimeter. UV spectra were recorded using a Shimadzu UV-1800 spectrometer (Shimadzu, Kyoto, Japan). The electronic circular dichroism (ECD) spectra were measured using a JASCO J-720W spectrometer (JASCO, Tokyo, Japan). High-resolution mass spectra were obtained using the MS system QTOF G6520 (Agilent Technologies) equipped with the HPLC-Chip Cube system G4240 (Agilent Technologies). The solvent used was $\mathrm{H}_{2} \mathrm{O}-\mathrm{CH}_{3} \mathrm{CN}(1: 1, v / v)$ containing $0.1 \% \mathrm{HCOOH}$.

\subsection{Materials}

Dried D. involucrata leaves were kindly provided by Dr. T. Yamaura, Yamashina Botanical Research Institute (Nippon Shinyaku Co. Ltd., Kyoto, Japan). Repandusinic acid A (6) was prepared from geraniin [30]. Toyopearl HW-40 (coarse and fine grades; Tosoh Corporation, Tokyo, Japan), YMC-gel ODS-A (S, 75 m; YMC), Sepabeads SP700, Dia-ion HP-20, and MCI-gel CHP-20P (Mitsubishi Chemical, Tokyo, Japan) were used for column chromatography. Dulbecco's modified Eagle's medium (DMEM) was obtained from GIBCO (BRL, Grand Island, NY, USA). Fetal bovine serum (FBS) and 3-(4,5-dimethylthiazol-2-yl)-2,5-diphenyltetrazolium bromide (MTT), were purchased from Sigma-Aldrich Inc. (St. Louis, MO, USA). Human normal oral cells [(gingival fibroblast (HGF), periodontal ligament 
fibroblast (HPLF), and pulp cells (HPC)) were established from the first premolar tooth extracted from the lower jaw of a 12-year-old girl [31]. Human oral squamous cell carcinoma (OSCC) cell lines (Ca9-22, HSC-2, HSC-3, and HSC-4) were purchased from Riken Cell Bank (Tsukuba, Japan).

\subsection{Isolation of Davicratinic Acid A (5)}

Dried D. involucrata leaves ( $230 \mathrm{~g}$ ) were homogenized in $70 \%$ aq. acetone at room temperature to yield aq. acetone extract ( $68.0 \mathrm{~g})$. A part $\left(20.0 \mathrm{~g}\right.$ ) of the obtained extract was re-dissolved in $\mathrm{H}_{2} \mathrm{O}$ and the solution was extracted with chloroform, ethyl acetate, and $n-\mathrm{BuOH}$ saturated with water, successively. The $n$ - $\mathrm{BuOH}$ extract ( $3.6 \mathrm{~g}$ ) was subjected to column chromatography over Sepabeads SP700 with increasing concentrations of $\mathrm{MeOH}$ in $\mathrm{H}_{2} \mathrm{O}$. The eluate $(184.1 \mathrm{mg})$ with $30 \%$ aq. $\mathrm{MeOH}$ was subjected to column chromatography over YMC-gel ODS-A with aq. $\mathrm{MeOH}$ to yield granatin A (2) (31.4 mg). The $40 \%$ aq. MeOH eluate from the Sepabeads column was re-chromatographed over YMC-gel ODS-A with aq. MeOH followed by preparative HPLC to afford pedunculagin (3) (1.0 mg). The eluate $(664.0 \mathrm{mg}$ ) from $60 \%$ aq. $\mathrm{MeOH}$ from the Sepabeads column was fractionated and purified by re-chromatography over Toyopearl HW-40C and YMC-gel ODS-A with aq. $\mathrm{MeOH}$ to give davidiin (1) $(47.0 \mathrm{mg})$ and 3-O-galloylgranatin $\mathrm{A}(4)(12.9 \mathrm{mg})$. The $\mathrm{H}_{2} \mathrm{O}$ extract $(8.1 \mathrm{~g})$ obtained after the $n$ - $\mathrm{BuOH}$ extraction was dissolved in $\mathrm{H}_{2} \mathrm{O}$ and the aq. solution was acidified to $<\mathrm{pH} 3$ with $1 \mathrm{M} \mathrm{HCl}$, and was subjected to column chromatography over Diaion HP-20 with aq. MeOH. The obtained 20\% $\mathrm{MeOH}$ eluate from the Diaion column $(718.5 \mathrm{mg}$ ) was fractionated and purified by chromatography over YMC-gel ODS-A (with aq. MeOH), Toyopearl HW-40F (with 70\% EtOH), and MCI-gel CHP-20P (with aq. $\mathrm{MeOH}$ ), followed by preparative HPLC, to yield davicratinic acid A (5) (8.2 mg).

Davicratinic acid $A$ (5): Pale-yellow amorphous powder; $[\alpha]_{D}^{19}-4.9(c=1.0, \mathrm{MeOH}) ; \mathrm{UV} \lambda_{\max }(\mathrm{MeOH}) \mathrm{nm}$

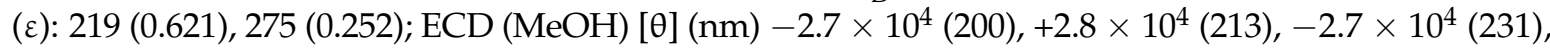
$+2.3 \times 10^{4}(244),-2.5 \times 10^{4}(261),+4.4 \times 10^{4}(284),-1.0 \times 10^{4}(319) ;{ }^{1} \mathrm{H}-\mathrm{NMR}$ (acetone- $d_{6} / \mathrm{D}_{2} \mathrm{O}=9 / 1$ ) $\delta: 3.93(1 \mathrm{H}, \mathrm{dd}, J=4.8,7.8 \mathrm{~Hz}, \mathrm{H}-4), 4.04(1 \mathrm{H}, \mathrm{dd}, J=4.8,11.4 \mathrm{~Hz}, \mathrm{H}-6 \mathrm{a}), 4.26(1 \mathrm{H}, \mathrm{dt}, J=4.8,11.4 \mathrm{~Hz}$, $\mathrm{H}-5), 4.60(1 \mathrm{H}, \mathrm{t}, J=11.4 \mathrm{~Hz}, \mathrm{H}-6 \mathrm{~b}), 5.13(1 \mathrm{H}, \mathrm{dd}, J=3.6,7.8 \mathrm{~Hz}, \mathrm{H}-2), 5.15\left(1 \mathrm{H}, \mathrm{br} \mathrm{s}, \mathrm{H}-2^{\prime}\right), 5.37(1 \mathrm{H}$, $\mathrm{t}, J=7.8 \mathrm{~Hz}, \mathrm{H}-3), 5.49\left(1 \mathrm{H}, \mathrm{br} \mathrm{s}, \mathrm{H}-3^{\prime}\right), 5.88(1 \mathrm{H}, \mathrm{d}, J=3.6 \mathrm{~Hz}, \mathrm{H}-1), 6.74\left(1 \mathrm{H}, \mathrm{s}, \mathrm{HHDP}-3^{\prime}\right), 6.83(1 \mathrm{H}$, s, H-5'), $6.89(1 \mathrm{H}, \mathrm{s}, \mathrm{HHDP}-3), 7.03\left(2 \mathrm{H}\right.$, s, galloyl-H), $7.10\left(1 \mathrm{H}, \mathrm{s}, \mathrm{H}-3^{\prime \prime}\right) .{ }^{13} \mathrm{C}-\mathrm{NMR}$ (acetone- $d_{6} / \mathrm{D}_{2} \mathrm{O}$ = 9/1) 8: $34.7\left(\mathrm{C}-3^{\prime}\right), 65.1$ (C-6), 68.9 (C-4), 72.0 (C-2), 72.2 (C-3), 78.2 (C-5), 78.8 (C-2'), 95.2 (C-1), 108.8 (HHDP-3'), 108.9 (C-3"'), 109.3 (HHDP-3), 110.0 (2C, C-2, 6), 115.0 (C-1"), 115.9 (HHDP-1), 116.1 (HHDP-1' $), 116.9$ (C-2"), 120.2 (galloyl-1), 124.8 (HHDP-2), 125.4 (HHDP-2'), 136.4 (HHDP-5), 136.6 (HHDP-5'), 137.3 (C-4'), 137.5 (C-5'), 139.3 (galloyl-4), 139.5 (C-5"), 144.0 (C-6"), 144.3 (2C, HHDP-4, 4'), 144.6 (HHDP-6), 144.9 (HHDP-6'), 145.3 (C-4"), 145.7 (2C, galloyl-3, 5), 165.5 (C-7'), 166.8 (C-7"), $166.9(2 \mathrm{C}, \mathrm{C}-1,3), 168.8\left(2 \mathrm{C}, \mathrm{C}-6,6^{\prime}\right), 171.4\left(\mathrm{C}-1^{\prime}\right)$. HR-ESI-MS m/z: $971.0952[\mathrm{M}+\mathrm{H}]^{+}$(calculated for $\left.\mathrm{C}_{41} \mathrm{H}_{31} \mathrm{O}_{28}+\mathrm{H}, 971.0996\right)$.

\subsection{Antibacterial Assay}

Two strains of MRSA, OM481 and OM584, clinical isolates from Okayama University Hospital that were stored in the Department of Microbiology Laboratory, were used in this study. Enterococcus faecium FN-1 and E. faecalis NCTC 12201 used in this study were provided by Prof. Y. Ike, Gunma University. The bacterial cells were pre-cultured in Mueller-Hinton broth at $37^{\circ} \mathrm{C}$ under aerobic conditions. They were incubated in the presence of compounds with final concentrations $16,32,64$, and $128 \mu \mathrm{g} / \mathrm{mL}$, obtained by two-fold serial dilution at $37^{\circ} \mathrm{C}$ without shaking, in the same broth, for $24 \mathrm{~h}$ on 96-well plates, as shown in a previous study $[24,32]$. The inoculates were adjusted to yield final cell density of about $10^{4} \mathrm{CFU}$. The lowest concentration at which visible growth was completely inhibited was regarded as the minimum inhibitory concentration (MIC). The same experiment was repeated at least three times and the values reproduced were given in Table 1. Dimethyl sulfoxide (DMSO) was used for dissolving compounds, and the final concentrations were set at $<5 \%$, where DMSO had no effect on bacterial growth. The positive control, linezolid, was used after dissolution in water. 


\subsection{Assay for Cytotoxic Activities}

Human normal oral cells (HGF, HPLF, HSC) and OSCC (Ca9-22, HSC-2, HSC-3, HSC-4) were cultured at $37^{\circ} \mathrm{C}$ in DMEM supplemented with $10 \%$ heat-inactivated FBS, 100 units $/ \mathrm{mL}$ of penicillin $\mathrm{G}$, and $100 \mu \mathrm{g} / \mathrm{mL}$ of streptomycin sulfate under a humidified $5 \% \mathrm{CO}_{2}$ atmosphere. Cells were then harvested by treatment with $0.25 \%$ trypsin- $0.025 \%$ EDTA-2Na in PBS (-) and either subcultured or used for experiments. The cells were inoculated at $2.5 \times 10^{3}$ cells $/ 0.1 \mathrm{~mL}$ in 96 -well microplates. After $48 \mathrm{~h}$, the medium was removed and replaced with $0.1 \mathrm{~mL}$ of fresh medium containing various concentrations of a test compound with three replicate wells. Each test compound was dissolved in DMSO at a concentration of $40 \mathrm{mM}$. The first well containing $400 \mu \mathrm{M}$ of the test compound was sequentially diluted two-fold. Control cells were treated with the same amounts of DMSO, and the cell damage induced by vehicle was corrected. The cells were incubated for an additional $48 \mathrm{~h}$, and the relative viable cell number was determined by the MTT method $[33,34]$. In brief, the treated cells were washed with phosphate-buffered saline and were incubated for another $3 \mathrm{~h}$ in fresh culture medium containing $0.2 \mathrm{mg} / \mathrm{mL}$ MTT. Cells were then lysed with $0.1 \mathrm{~mL}$ of DMSO and the absorbance of the cell lysate at $540 \mathrm{~nm}$ was determined using a microplate reader (Bichromatic Labsystem, Helsinki, Finland). Absorbance of the control cells ranged from 0.40 to 0.90 . The $50 \%$ cytotoxic concentration $\left(C_{50}\right)$ was determined from the dose-response curve and the mean value of $\mathrm{CC}_{50}$ for each cell type was calculated from three independent experiments. The antitumor potential was evaluated by the tumor-specificity index (TS). TS value was calculated by the following equation: $\mathrm{TS}=$ mean $\mathrm{CC}_{50}$ against normal cells / mean $\mathrm{CC}_{50}$ against tumor cells that is $\left[\mathrm{CC}_{50}(\mathrm{HGF})+\mathrm{CC}_{50}(\mathrm{HPLF})+\mathrm{CC}_{50}(\mathrm{HPC})\right] /\left[\mathrm{CC}_{50}(\mathrm{Ca} 9-22)\right.$ $+\mathrm{CC}_{50}$ (HSC-2) $+\mathrm{CC}_{50}$ (HSC-3) $+\mathrm{CC}_{50}$ (HSC-4) $] \times 4 / 3$. We have previously confirmed that the TS value determined by this method reflects the antitumor potential of test samples, although these normal oral cells and OSCC cell lines are classified as mesenchymal or epithelial cells [34].

\section{Conclusions}

The findings obtained in the present study indicate that $D$. involucrata is an important tannin-rich resource. In particular, ellagitannin 1, which possesses the unique skew-boat-type glucopyranose core, is abundant in this plant. In this study, we investigated new ellagitannins of this plant, and characterized the new tannin $\mathbf{5}$, which also has a skew-boat glucopyranose core. We consider that 5 is metabolized from 4 via oxidation of the DHHDP moiety [35], and have shown that $\mathbf{1}$ is a prominent antibacterial compound. The anti-MRSA activity of ellagitannins has been previously reported [10]; to the best of our knowledge, the anti-VRE activity of tannins has not been demonstrated before this study. Although the mechanisms for the cytotoxicity remain unclear, we expect that $\mathbf{1}$ is a possible candidate for a lead compound for antitumor agents. Further studies will be needed to isolate other ellagitannins related to 1 from $D$. involucrata, and will be important in understanding the tannin metabolism in plants; examination of the structure-activity relationship of these tannins on antibacterial and antitumor effects will also be important.

Supplementary Materials: Supplementary materials are available online.

Acknowledgments: The authors gratefully thank T. Yamaura, Nippon Shinyaku, for providing the plant material, and the Division of Instrumental Analysis, Department of Instrumental Analysis \& Cryogenics, Advanced Science Research Center, Okayama University, for NMR and MS measurements. This study was supported in part by a Grant-in-Aid from the Japan Society for the Promotion of Science (JSPS) (25450170).

Author Contributions: The contributions of the respective authors are as follows: Y. Shimozu performed structure elucidation of the constituents, especially the interpretation of the NMR spectra, and prepared the manuscript. Y. Kimura and A. Esumi contributed to the isolation and the identification the constituents. H. Aoyama contributed to the MS measurements and the interpretation of those spectra. T. Kuroda contributed to the antibacterial experiments. H. Sakagami contributed to the antitumor experiments. This study was performed based on the planning of T. Hatano, the corresponding author.

Conflicts of Interest: The authors declare no conflict of interest. 


\section{References}

1. Melchior, H.E.; Werdermann, E. A. Engler's Syllabus der Pflanzenfamilien, 12th ed.; Grbrüder Borntraeger: Berlin, Germany, 1964; Volume 2.

2. Wu, Z.J.; Ouyang, M.A.; Wang, S.B. Two new phenolic water-soluble constituents from branch bark of Davidia involucrata. Nat. Prod. Res. 2008, 22, 483-488. [CrossRef] [PubMed]

3. Tan, Q.W.; Ouyang, M.A.; Gao, B. Three new ring-A modified ursane triterpenes from Davidia involucrata. Molecules 2014, 19, 4897-4906. [CrossRef] [PubMed]

4. Tan, Q.W.; Ouyang, M.A.; Chen, Q.J.; Wu, Z.J. Five new taraxerene-type triterpenes from the branch barks of Davidia involucrata. Molecules 2014, 19, 17619-17631. [CrossRef] [PubMed]

5. Haddock, E.A.; Gupta, R.K.; Haslam, E. The metabolism of gallic acid and hexahydroxydiphenic acid in plants 3. Esters of $(R)$-hexahydroxydiphenic and $(S)$-hexahydroxydiphenic acid and dehydrohexahydroxydiphenic acid with D-glucopyranose ( $\left({ }^{1} \mathrm{C}_{4}\right.$ and related conformations). J. Chem. Soc. Perkin Trans. I 1982, 11, 2535-2545. [CrossRef]

6. Okuda, T. Systematics and health effects of chemically distinct tannins in medicinal plants. Phytochemistry 2005, 66, 2012-2031. [CrossRef] [PubMed]

7. Okuda, T.; Yoshida, T.; Hatano, T.; Ito, H. Ellagitannins renewed the concept of tannins. In Chemistry and Biology of Ellagitannins; Quideu, S., Ed.; World Scientific Publishing: Singapore, 2009; Chapter 1; pp. 1-54.

8. Takemoto, M.; Kawamura, Y.; Hirohama, M.; Yamaguchi, Y.; Handa, H.; Saitoh, H.; Nakao, Y.; Kawada, M.; Khalid, K.; Koshino, H.; et al. Inhibition of protein SUMOylation by davidiin, an ellagitannin from Davidia involucrata. J. Antibiot. 2014, 67, 335-338. [CrossRef] [PubMed]

9. Horiuchi, K.; Shiota, S.; Hatano, T.; Yoshida, T.; Kuroda, T.; Tsuchiya, T. Antimicrobial activity of oleanolic acid from Salvia officinalis and related compounds on vancomycin-resistant Enterococci (VRE). Biol. Pharm. Bull. 2007, 30, 1147-1149. [CrossRef] [PubMed]

10. Hatano, T.; Kusuda, M.; Inada, K.; Ogawa, T.O.; Shiota, S.; Tsuchiya, T.; Yoshida, T. Effects of tannins and related polyphenols on methicillin-resistant Staphylococcus aureus. Phytochemistry 2005, 66, 2047-2055. [CrossRef] [PubMed]

11. Eerdunbayaer; Orabi, M.A.; Aoyama, H.; Kuroda, T.; Hatano, T. Structures of two new flavonoids and effects of licorice phenolics on vancomycin-resistant Enterococcus species. Molecules 2014, 19, 3883-3897. [CrossRef] [PubMed]

12. Eerdunbayaer; Orabi, M.A.; Aoyama, H.; Kuroda, T.; Hatano, T. Structures of new phenolics isolated from licorice, and the effectiveness of licorice phenolics on vancomycin-resistant Enterococci. Molecules 2014, 19, 13027-13041. [CrossRef] [PubMed]

13. Ito, H.; Miyake, M.; Nishitani, E.; Mori, K.; Hatano, T.; Okuda, T.; Konoshima, T.; Takasaki, M.; Kozuka, M.; Mukainaka, T.; et al. Anti-tumor promoting activity of polyphenols from Cowania mexicana and Coleogyne ramosissima. Cancer Lett. 1999, 143, 5-13. [CrossRef]

14. Okabe, S.; Suganuma, M.; Imayoshi, Y.; Taniguchi, S.; Yoshida, T.; Fujiki, H. New TNF-alpha releasing inhibitors, geraniin and corilagin, in leaves of Acer nikoense, Megusurino-ki. Biol. Pharm. Bull. 2001, 24, 1145-1148. [CrossRef] [PubMed]

15. Okuda, T.; Mori, K.; Hayatsu, H. Inhibitory effect of tannins on direct-acting mutagens. Chem. Pharm. Bull. 1984, 32, 3755-3758. [CrossRef] [PubMed]

16. Wang, Y.; Ma, J.; Chow, S.C.; Li, C.H.; Xiao, Z.; Feng, R.; Fu, J.; Chen, Y. A potential antitumor ellagitannin, davidiin, inhibited hepatocellular tumor growth by targeting EZH2. Tumor Biol. 2014, 35, 205-212. [CrossRef] [PubMed]

17. Orabi, M.A.; Taniguchi, S.; Yoshimura, M.; Yoshida, T.; Kishino, K.; Sakagami, H.; Hatano, T. Hydrolyzable tannins of tamaricaceous plants. III. Hellinoyl- and macrocyclic-type ellagitannins from Tamarix nilotica. J. Nat. Prod. 2010, 73, 870-879. [CrossRef] [PubMed]

18. Orabi, M.A.; Taniguchi, S.; Sakagami, H.; Yoshimura, M.; Yoshida, T.; Hatano, T. Hydrolyzable tannins of tamaricaceous plants. V. Structures of monomeric-trimeric tannins and cytotoxicity of macrocyclic-type tannins isolated from Tamarix nilotica (1). J. Nat. Prod. 2013, 76, 947-956. [CrossRef] [PubMed]

19. Orabi, M.A.; Taniguchi, S.; Sakagami, H.; Yoshimura, M.; Amakura, Y.; Hatano, T. Hydrolyzable Tannins of Tamaricaceous Plants. 7.1 Structures and Cytotoxic Properties of Oligomeric Ellagitannins from Leaves of Tamarix nilotica and Cultured Tissues of Tamarix tetrandra. J. Nat. Prod. 2016, 79, 984-995. [CrossRef] [PubMed] 
20. Hatano, T.; Hattori, S.; Ikeda, Y.; Shingu, T.; Okuda, T. Gallotannins having a 1,5-anhydro-D-glucitol core and some ellagitannins from Acer species. Chem. Pharm. Bull. 1990, 38, 1902-1905. [CrossRef]

21. Okuda, T.; Yoshida, T.; Ashida, M.; Yazaki, K. Tannins of Casuarina and Stachyurus Species, Part 1. Structure of Pedunculagin, Casuarictin, Strictinin, Casuarinin, Casuariin, and Stachyurin. J. Chem. Soc. Perkin Trans. I 1983, 1765-1771. [CrossRef]

22. Lee, S.H.; Tanaka, T.; Nonaka, G.; Nishioka, I. Tannins and related compounds. XCV. Isolation and characterization of helioscopinins and helioscopins, four new hydrolysable tannins from Euphorbia helioscopia L. (1). Chem. Pharm. Bull. 1990, 38, 1518-1523. [CrossRef]

23. Saijo, R.; Nonaka, G.; Nishioka, I. Tannins and Related Compounds. LXXXVII: Isolation and Characterization of Four New Hydrolyzable Tannins from the Leaves of Mallotus repandus. Chem. Pharm. Bull. 1989, 37, 2624-2630. [CrossRef]

24. Hatano, T.; Uebayashi, H.; Ito, H.; Shiota, S.; Tsuchiya, T.; Yoshida, T. Phenolic constituents of Cassia seeds and antibacterial effect of some naphthalenes and anthraquinones on methicillin-resistant Staphylococcus aureus. Chem. Pharm. Bull. 1999, 47, 1121-1127. [CrossRef] [PubMed]

25. Din, W.M.; Jin, K.T.; Ramli, R.; Khaithir, T.M.N.; Wiart, C. Antibacterial effects of ellagitannins from Acalypha wilkesiana var. macafeana hort.: Surface morphology analysis with environmental scanning with electron microscopy and synergy with antibiotics. Phytother. Res. 2013, 27, 1313-1320. [PubMed]

26. Caturla, N.; Vera-Samper, E.; Villalain, J.; Mateo, C.R.; Micol, V. The relationship between the antioxidant and the antibacterial properties of galloylated catechins and the structure of phospholipid model membranes. Free Radic. Biol. Med. 2003, 34, 648-662. [CrossRef]

27. Miyamoto, K.; Kishi, N.; Koshiura, R.; Yoshida, T.; Hatano, T.; Okuda, T. Relationship between the structures and the antitumor activities of tannins. Chem. Pharm. Bull. 1987, 35, 814-822. [CrossRef] [PubMed]

28. Sakagami, H.; Jiang, Y.; Kusama, K.; Atsumi, T.; Ueha, T.; Toguchi, M.; Iwakura, I.; Satoh, K.; Ito, H.; Hatano, T.; et al. Cytotoxic activity of hydrolyzable tannins against human oral tumor cell lines-A possible mechanism. Phytomedicine 2000, 7, 39-47. [CrossRef]

29. Sakagami, H.; Kobayashi, M.; Chien, C.H.; Kanegae, H.; Kawase, M. Selective toxicity and type of cell death induced by various natural and synthetic compounds in oral squamous cell carcinoma. In Vivo 2007, 21, 311-320. [PubMed]

30. Taniguchi, S.; Nogaki, R.; Bao, L.M.; Kuroda, T.; Ito, H.; Hatano, T. Furosonin, a Novel Hydrolyzable Tannin from Geranium thunbergii. Heterocycles 2012, 86, 1525-1532.

31. Kantoh, K.; Ono, M.; Nakamura, Y.; Nakamura, Y.; Hashimoto, K.; Sakagami, H.; Wakabayashi, H. Hormetic and anti-radiation effects of tropolone-related compounds. In Vivo 2010, 24, 843-852. [PubMed]

32. Okamura, S.; Nishiyama, E.; Yamazaki, T.; Otsuka, N.; Taniguchi, S.; Ogawa, W.; Hatano, T.; Tsuchiya, T.; Kuroda, T. Action mechanism of 6,6'-dihydroxythiobinupharidine from Nuphar japonicum, which showed anti-MRSA and anti-VRE activities. Biochim. Biophys. Acta 2015, 1850, 1245-1252. [CrossRef] [PubMed]

33. Shimada, C.; Uesawa, Y.; Ishii-Nozawa, R.; Ishihara, M.; Kagaya, H.; Kanamoto, T.; Terakubo, S.; Nakashima, H.; Takao, K.; Sugita, Y.; et al. Quantitative structure-cytotoxicity relationship of 3-styrylchromones. Anticancer Res. 2014, 34, 5405-5412. [PubMed]

34. Suzuki, R.; Matsuno, S.; Sakagami, H.; Okada, Y.; Shirataki, Y. Search of new cytotoxic crude materials against human oral squamous cell carcinoma using ${ }^{1} \mathrm{H}-\mathrm{NMR}$-based metabolomics. Anticancer Res. 2014, 34, 4117-4120. [PubMed]

35. Tanaka, T.; Nonaka, G.; Nishioka, I. Tannins and Related Compounds. C.: Reaction of Dehydrohexahydroxydiphenic Acid Esters with Bases, and Its Application to the Structure Determination of Pomegranate Tannins, Granatins A and B. Chem. Pharm. Bull. 1990, 38, 2424-2428. [CrossRef]

Sample Availability: Sample of the compound 5 is available from the authors.

(C) 2017 by the authors. Licensee MDPI, Basel, Switzerland. This article is an open access article distributed under the terms and conditions of the Creative Commons Attribution (CC BY) license (http://creativecommons.org/licenses/by/4.0/). 